\title{
ISPITIVANJE POLOŽAJNE TOČNOSTI GRANICA ŠUMSKIH PODRUČJA DOBIVENIH OBJEKTNO - ORIJENTIRANOM KLASIFIKACIJOM MULTISPEKTRALNIH SNIMAKA
}

\author{
POSITIONAL ACCURACY ASSESSMENT OF FOREST AREA \\ BOUNDARIES OBTAINED BY OBJECT - ORIENTED \\ CLASSIFICATION OF MULTISPECTRAL IMAGERY
}

Nedim TUNO ${ }^{*}$, Admir MULAHUSIĆ* , Jusuf TOPOLJAK', Alma ELEZOVIĆ**

\begin{abstract}
Sažetak
Poznavanje položajne točnosti geoprostornih informacija o šumama, dobivenih interpretacijom satelitskih snimaka, ima veliko značenje. Posljedice odluka koje su temeljene na podacima nedovoljne ili nepoznate kvalitete mogu biti vrlo negativne. $U$ ovome radu istražena je točnost zatvorenih linijskih objekata kojima su predstavljene granice šumskog pokrova. Implementacijom postupka segmentacije snimke korištenjem svih multispektralnih kanala te klasifikacijom tako definiranih segmenata pomoću posebnih pravila, efikasno su izdvojene površine pod šumama. Empirijskom analizom temeljenom na usporedbi testnog i referentnog linijskog sadržaja, pokazano je da kartografska generalizacija doprinosi poboljšanju točnosti granica šuma, te da adekvatna obrada podataka daljinskih istraživanja srednje prostorne rezolucije može rezultirati vektorskim podacima zadovoljavajuće kvalitete.
\end{abstract}

KLJUČNE RIJEČI: Landsat, objektno - orijentirana klasifikacija šuma, kartografska generalizacija, položajna točnost

\section{UVOD}

\section{INTRODUCTION}

Daljinska istraživanja u posljednjim desetljećima predstavljaju nezaobilazanu metodu prikupljanja informacija za kartiranje i nadzor šuma (Franklin 2001). Primjenom satelitskih snimaka srednjih prostornih rezolucija često se obavlja kartiranje vegetacijskog pokrova. Pri tome se mogu s pouzdanošću koristiti besplatne multispektralne satelitske snimke Landsat (Seletković i sur. 2008). Klasifikacijom rasterskih snimaka, koje su pogodne za različite prikaze i vizualne analize, dobivaju se kvantitativni slojevi pogodni za analize unutar GIS sustava i izradu karata (Mulahusić i Tuno 2011, Oštir i Mulahusić 2014). U posljednje vrijeme je značajan napredak ostvaren razvojem algoritama objektno-orijentirane klasifikacije, temeljenim na objedinjenim

doc. dr. sc. Nedim Tuno, nedim tuno@gf.unsa.ba, nedim tu@yahoo.com, izv. prof. dr. sc. Admir Mulahusić, doc. dr. sc. Jusuf Topoljak, Univerzitet u Sarajevu, Građevinski fakultet, Odsjek za geodeziju, Stjepana Tomića 1/III, 71000 Sarajevo,BiH, e-mail: admir_mulahusic@gf.unsa.ba, jusuf_topoljak@gf.unsa.ba.

**Alma Elezović, Općina Visoko, Alije Izetbegovića 12A, 71300 Visoko, BiH, e-mail: elezovicalmaa@gmail.com

* autor za korespondenciju corresponding author 


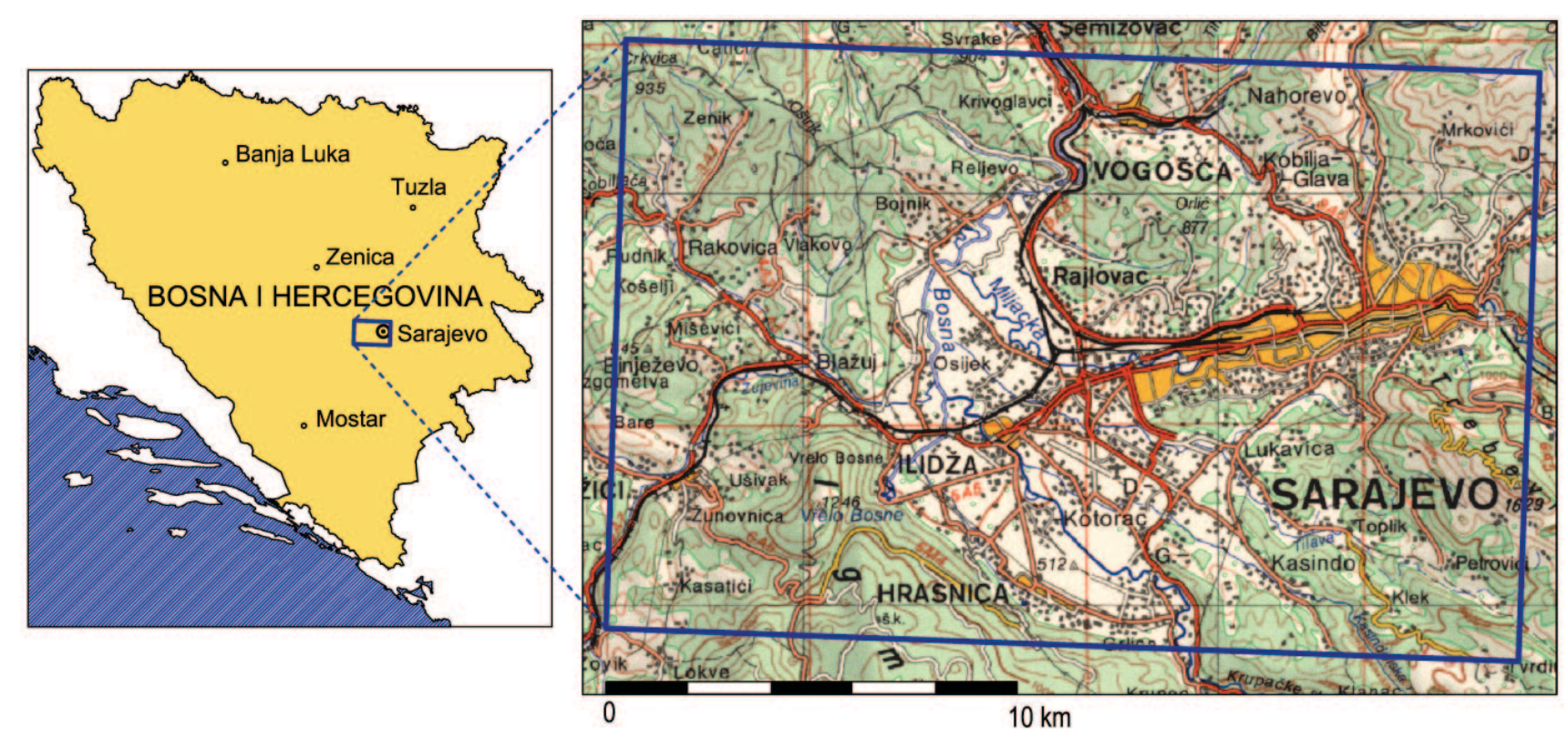

Slika 1. Područje istraživanja.

Figure 1. Research area.

skupinama piksela ili objekata stvorenim segmentacijom snimaka (Valožić 2014, Govedarica i sur. 2015).

Linijski elementi kojima se aproksimiraju granice šumskih područja, dobiveni klasifikacijom satelitskih snimaka, često sadrže nepoželjne nepravilnosti u vidu drhtavosti, nazubljenosti ili vijugavosti vektorskih linija. Stoga je nužno provesti kartografsku generalizaciju, tj. izglađivanje linija, kojom se uklanjaju nepravilnosti i grubosti sa neke linije unutar zadane tolerancije (Tutić i Lapaine 2009, Frančula i Lapaine 2008). Dosadašnja istraživanja vezana uz izglađivanje linijskih objekata (PAEK engl. Polynomial Approximation with Exponential Kernel - polinomna aproksimacija s eksponencijalnom jezgrom) dobivenih klasifikacijom satelitskih snimaka (Heinonen i sur. 2007, Saeedrashed 2014, Tarmizi i sur. 2014, Giannini i Parente 2015) ukazala su na dobre karakteristike te metode.

Kvaliteta klasificiranih geoprostornih objekata uobičajeno se određuje unutar softvera za klasifikaciju satelitskih snimaka, koji imaju ugrađene algoritme za procjenu točnosti. Podloga provjere točnosti je matrica pogrešaka, koja se formira na temelju usporedbe referentnih podataka s rezultatima klasifikacije. Takav su način ocjene točnosti klasificiranog vegetacijskog pokrova u svojim istraživanjima primijenili Seletković i sur. (2008), Valožić (2014), Govedarica i sur. (2015) i mnogi drugi. Problem ovakve procjene točnosti je da ne pruža informacije o apsolutnoj položajnoj točnosti, koja predstavlja jedan od najvažnijih kriterija za ocjenjivanje kvalitete geoprostornih podataka. Pod položajnom točnošću podrazumijeva se podudarnost položaja nekog objekta u modelu geoprostora sa stvarnim položajem tog objekta u prostoru. U seriji normi ISO 19100 Geograp- hic Information, nekoliko normi se bavi kvalitetom podataka, ali se tek na nacionalnoj razini javljaju pojedine norme koje pobliže uređuju ovu problematiku (Ariza i Atkinskon 2008, Radojčić i sur. 2011). Norme su zasnovane na usporedbi koordinata točaka izmjerenih u skupu, čija se točnost ocjenjuje i odgovarajućih referentnih koordinata. Situacija je mnogo kompliciranija kod linija i poligona, jer su njihova odstupanja skup položajnih pogrešaka koje variraju uzduž linije. Ocjenu položajne točnosti linijskih objekata analizirali su Goodchild i Hunter (1996), Skopeliti i Tsoulos (2000) i Ruiz-Lendínez i sur. (2013).

Osnovni cilj ovog istraživanja je iznalaženje načina kojim će se za potrebe izrade geoinformacijskih sustava i karata, na temelju podataka objektno-orijentirane klasifikacije Landsat snimke, osigurati pouzdana dijagnostika položajne kvalitete šumskih prostornih entiteta.

\section{MATERIJALI I METODE MATERIALS AND METHODS}

\section{Područje istraživanja - Research area}

Istraživanje položajne točnosti obrisa šumskih kompleksa obavljeno je na širem području grada Sarajeva (slika 1), koje se nalazi u središnjem dijelu Bosne i Hercegovine. Analizirani teren predstavlja izrazito brdsko područje s rasponom nadmorskih visina od $470 \mathrm{~m}$ do $1.630 \mathrm{~m}$ (prosjek $700 \mathrm{~m}$ ), pri čemu $29 \%$ teritorija pripada planinskom području iznad 700 m nadmorske visine, $45 \%$ pripada brdskom području od 550 do $700 \mathrm{~m}$, dok $26 \%$ prostora pripada nizinskom području do $550 \mathrm{~m}$ nadmorske visine. Osim Sarajevskog polja i dolina rijeka Bosne i Miljacke, teren je vrlo neravan i izlomljen, s izraženim nagibom. 


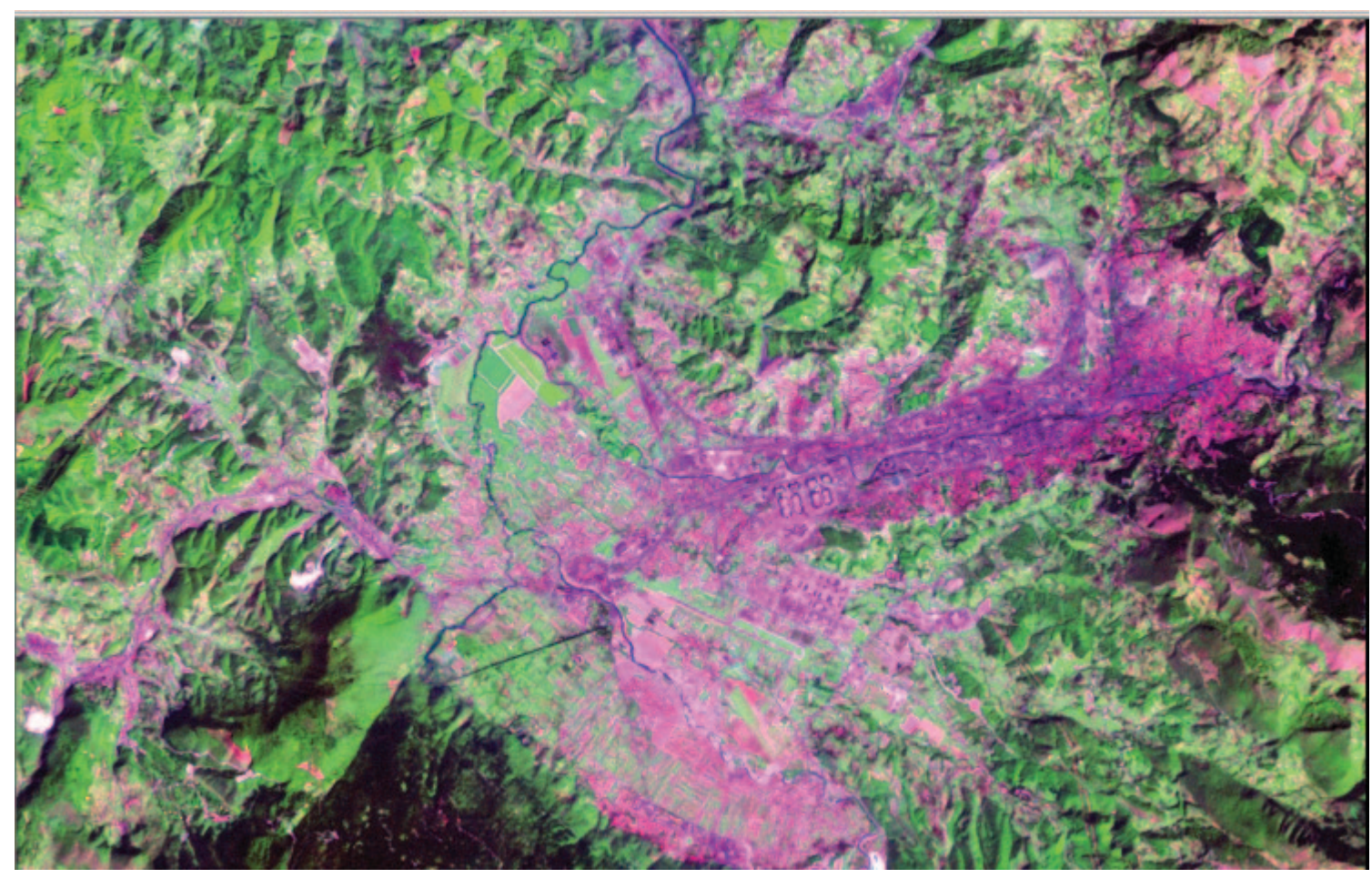

Slika 2. Landsat TM satelitska snimka područja istraživanja iz 1986. godine (kanali 7, 4, 2).

Figure 2 Landsat TM image of the research area from 1986 (bands 7, 4, 2).

Područje istraživanja obuhvaća površinu $318 \mathrm{~km}^{2}(22.2 \mathrm{x}$ $14,3 \mathrm{~km}$ ), od čega područje pokriveno šumom iznosi oko $45 \%$. Prema Vojnikoviću i sur. (2013), u sarajevskoj regiji na području pod šumskim pokrovom prevladavaju mezofilne listopadne šume (59\%), mezofilne crnogorične šume (20\%) i mezofilne mješovite šume (9\%).

\section{Satelitska snimka - Satellite image}

U okviru istraživanja obrađena je Landsat 5 TM (engl. Thematic Mapper) satelitska snimka, iz 1986. godine (slika 2). Oblačnost je $0 \%$, a ukupna ocjena kvalitete snimke je 9 . Prostorni podaci snimke registrirani su u referentnom koordinatnom sustavu UTM kartografske projekcije (engl. Universal Transverse Mercator) s geodetskim datumom WGS 84 (engl. World Geodetic System 1984). Prostorna rezolucija iznosi $30 \mathrm{~m}$ za sve kanale, osim termalnog u kojem je prostorna rezolucija $120 \mathrm{~m}$. Spektralna rezolucija obuhvaća 7 kanala elektromagnetskoga spektra. Vrijednosti svih kanala su u rasponu od 0 do 255, čemu odgovara 8-bitna radiometrijska rezolucija (Oštir i Mulahusić 2014). Apsolutna položajna točnost (srednja kvadratna pogreška) objekata na ortorektificiranim snimkama bolja je od $50 \mathrm{~m}$ (Tucker i sur. 2004).

\section{Topografske karte - Topographic maps}

Podatke dobivene obradom Landsat snimke sa ciljem procjene položajne točnosti granica šumskoga zemljišta, potrebno je usporediti s neovisnim referentnim skupom po- dataka određenih s većom položajnom točnosti u odnosu na podatke koji se testiraju. U tu svrhu poslužilo je 6 listova topografske karte mjerila 1:25 000 (TK25, oznake listova su: 525-1-2, 525-1-4, 525-2-1, 525-2-2, 525-2-3 i 525-2-4), izrađenih 1986. godine od strane Vojno geografskog instituta iz Beograda, na temelju podataka aerofotogrametrijske izmjere. Na spomenutim listovima tematska cjelina šumskog pokrova predstavlja bitan geografski element sadržaja karte. Horizontalni podaci TK25 su u referentnom koordinatnom sustavu Gauss-Krügerove kartografske projekcije, 6. zona, s referentnom plohom elipsoida Bessel 1841 i datumskom točkom Hermannskögel. Kako bi se podaci o granicama šumskih cjelina, prikazani na TK25, mogli koristiti za potrebe ovog istraživanja, bilo ih je potrebno prevesti iz analognog u digitalni vektorski oblik. Pri tome je prijenos sadržaja grafičkih izvornika TK25 u digitalni zapis obavljen putem ručne ekranske vektorizacije na rasterskim slikama dobivenim skeniranjem analogne karte (slika 3).

Položajna točnost digitaliziranih šumskih granica ovisi o utjecajima deformacija kartografskog papira, nepravilnostima skeniranja, pogreškama vektorizacije i pogreškama izrade analognih karata (Tuno, 2014). Prva tri izvora pogrešaka su ovdje u velikoj mjeri eliminirana adekvatnim postupkom geometrijske transformacije skeniranih listova karte i velikom pozornošću pri ekranskoj vektorizaciji. S tim u svezi može se realno pretpostaviti da će očekivana položajna točnost digitaliziranih obrisa šumskih površina praktički ovisiti jedino o točnosti kartiranja kontura vege- 

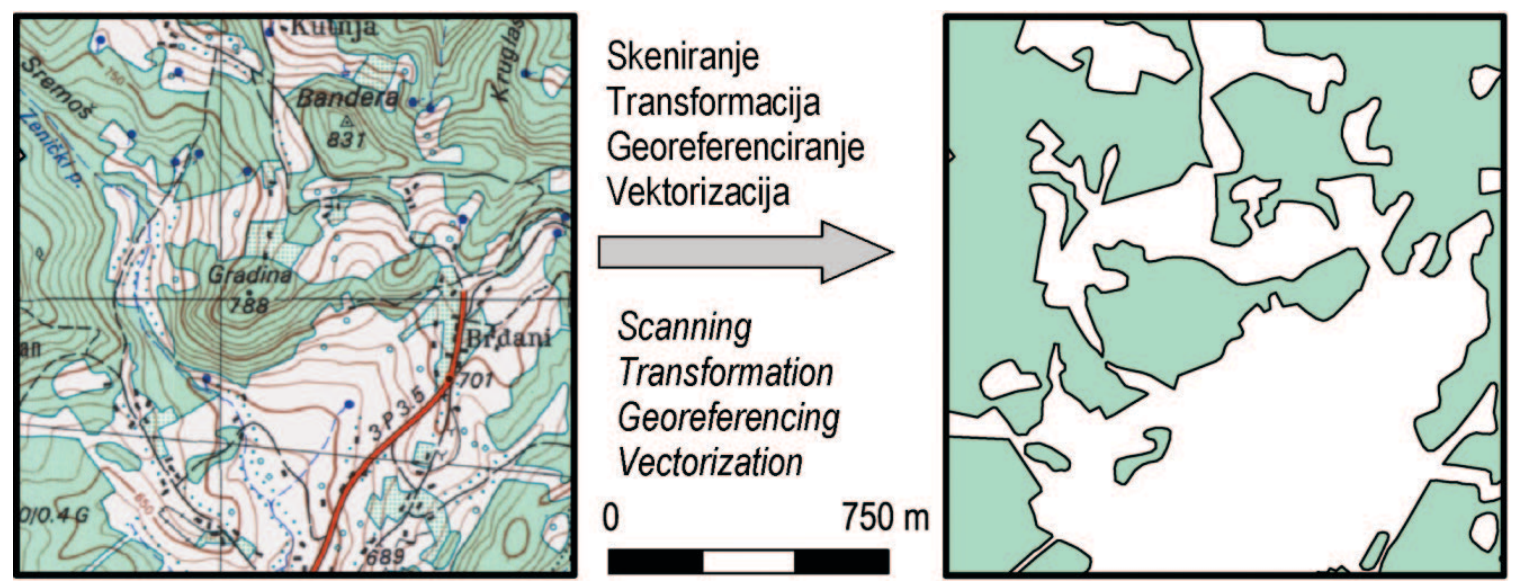

Slika 3. Proces izrade digitalnih topografskih podataka (tematska cjelina šume, prikazano na isječku lista 525-1-2).

Figure 3. The process of digital topographic data creation (thematic class forest, presented on the clip of map sheet 525-1-2).

tacije na izvornicima TK25, koja iznosi oko $10 \mathrm{~m}$ (Ključanin i sur. 2011, Puceković 2014). To je približno pet puta bolje od očekivane točnosti Landsat snimaka (Tucker i sur. 2004), čime su zadovoljeni kriteriji točnosti za referentne podatke (Tuno 2014).

Objektno - orijentirana klasifikacija satelitske snimke - Object-oriented classification of the satellite image

Postupak klasifikacije šumskih područja je u osnovi utemeljen na segmentaciji satelitske snimke (Govedarica i sur. 2015). U ovom slučaju snimka je segmentirana pomoću al- goritma nazvanog multirezolucijska segmentacija, koji je implementiran u okviru programskog paketa eCognition Developer. Taj algoritam među svim metodama segmentacije daje najbolje rezultate, a temelji se na pristupu odozdo prema gore (engl. bottom-up), gdje se zasebni pikseli grupiraju u regije za koje se pretpostavlja da pripadaju istom objektu (Valožić 2014, Trimble: eCognition Essentials, http://www. ecognition.com). Broj objekata koji se dobiju segmentacijom, ovisi o odabranom mjerilu segmentacije, koje određuje količinu spektralne varijacije unutar objekata i njihovu rezultirajuću veličinu. Što je mjerilo manje, broj segmenata je veći i obratno. Podešavanjem omjera između tzv. boje (color)

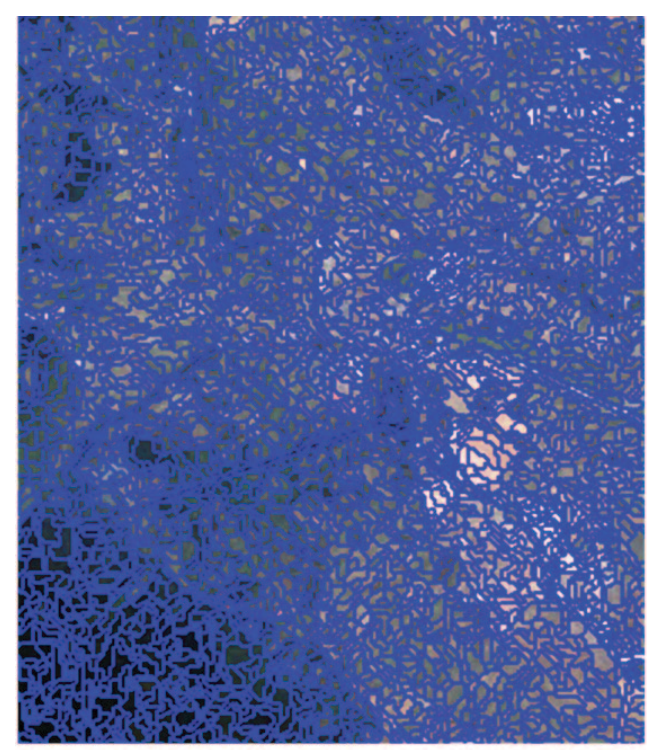

A

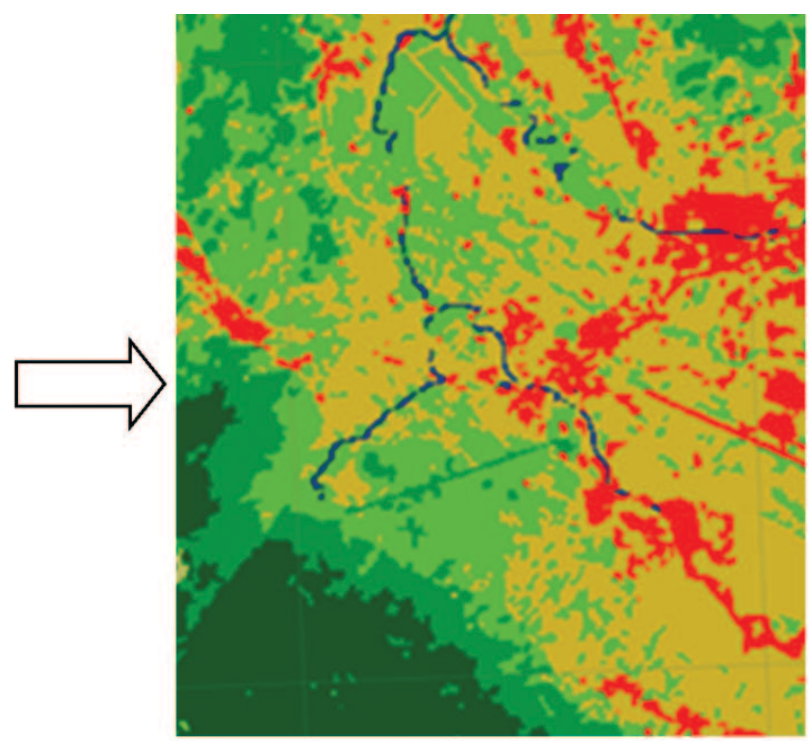

B

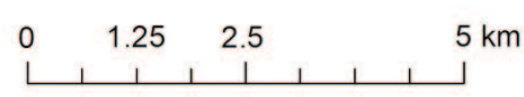

Crnogorična šuma / Coniferous forest

Bjelogorična šuma / Deciduous forest

Slika 4. Rezultati segmentacije (A) i klasifikacije (B) satelitske snimke.

Figure 4. The results of satellite image segmentation (A) and classification (B). 
Tablica 1. Točnost objektno - orijentirane klasifikacije satelitske snimke.

Table 1. Accuracy of satellite image object-oriented classification.

\begin{tabular}{lcc}
\multicolumn{1}{c}{ Klasa } & Crnogorična šuma & Bjelogorična šuma \\
Coniferous forest & Deciduous forest
\end{tabular}

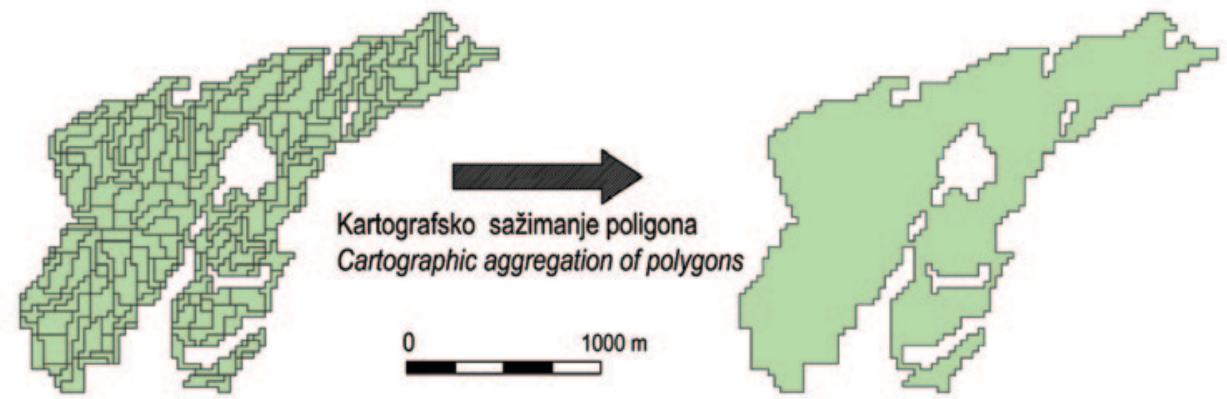

Slika 5. Kartografsko sažimanje 238 susjednih segmenata klasificiranih kao šume u jedan šumski poligon površine 1,9km². Figure 5. Cartographic aggregation of 238 adjacent segments classified as forest into a one forest polygon whose area is $1.9 \mathrm{~km}^{2}$.

i oblika (shape) daje se manja ili veća važnost spektralnim svojstvima piksela. Na kompaktnost (compactness) segmenata, odnosno njihovih granica također se može utjecati odabirom posebnog parametra (Valožić 2014).

Nakon provođenja većeg broja eksperimenata došlo se do zaključka da optimalna vrijednost mjerila segmentacije iznosi 3. Za sve korištene kanale parametru boja dodijeljena je vrijednost 1 . Parametar oblika dobio je vrijednost 0,1 , dok je za parametar kompaktnosti uzeta vrijednost 0,5 . Segmentacijom provedenom na ovaj način dobivena su 43 202 segmenta (slika 4). Veći broj segmenata se pokazao boljim za proces klasifikacije.

Nakon završenog procesa segmentacije, prelazi se na klasifikaciju, odnosno razvrstavanje tih segmenata u željene klase. Klasifikacija je obavljena definiranjem svake klase zasebno, pisanjem pravila u samom softveru. Za postavljanje različitih uvjeta pomoću kojih je snimka klasificirana, koristili su se pojedinačni kanali snimke, te različiti indeksi koji su dobiveni kombinacijama različitih kanala i operacija među njima. Uporabljeni su indeksi: NDVI, NDSII, LWM, NDWI, NBR, RVI, GNDVI i SLAVI. Odabir numeričkih intervala koji su korišteni u uvjetima, izvršen je nakon više pokušaja i zaključka da daju najbolje rezultate. Velika prednost ove klasifikacije je što se nakon završene klasifikacije pogrešno klasificirani segmenti mogu ručno popraviti.

Ocjena točnosti objektno-orijentirane klasifikacije obavljena je pomoću uzoraka (ručno odabranih segmenata) za koje je poznat stvarni način uporabe zemljišta. Usporedbom 99 takvih segmenata s klasificiranim segmentima, dobiveni su pokazatelji različitih mjera točnosti, koji su prikazani u tablici 1 . S obzirom da u svim slučajevima točnost iznosi iznad 90 \%, može se zaključiti, kako je klasifikacijom obavljen dobar odabir interpretiranih klasa prema stvarnom stanju na terenu (Oštir i Mulahusić 2014).

\section{Kartografsko sažimanje - Cartographic aggregation}

Rezultati klasifikacije satelitske snimke pohranjeni su u vektorski podatkovni format SHP (Shapefile) tvrtke ESRI i uvedeni u ArcGIS okruženje. Na taj su način dobivena 43202 poligona, koji odgovaraju klasificiranim segmentima. S obzirom da su za površine pod šumama postojala 15.352 takva poligona (prosječna površina segmenta iznosila je 9,2 ha), što nije adekvatno za dalje analize, bilo je neophodno obaviti njihovo sažimanje (aggregation) u ArcGIS-u (Droppová 2011). Sažimanje je proces kartografske generalizacije koji podrazumijeva grafičko spajanje susjednih istovrsnih objekata, kad je razmak između njih manji od minimalnih veličina (Frančula 2003). Nakon provedenog sažimanja (slika 5) dobiveno je 414 šumskih poligona ukupne površine $141,35 \mathrm{~km}^{2}$, što znači da je izvorni broj poligona smanjen 37 puta.

\section{REZULTATI I RASPRAVA RESULTS AND DISCUSSION}

\section{Kartografsko izglađivanje - Cartographic smoothing}

Nakon provedenog sažimanja dobiveni su obrisi šumskih kompleksa u obliku pikseliziranih (nazubljenih) zatvorenih 

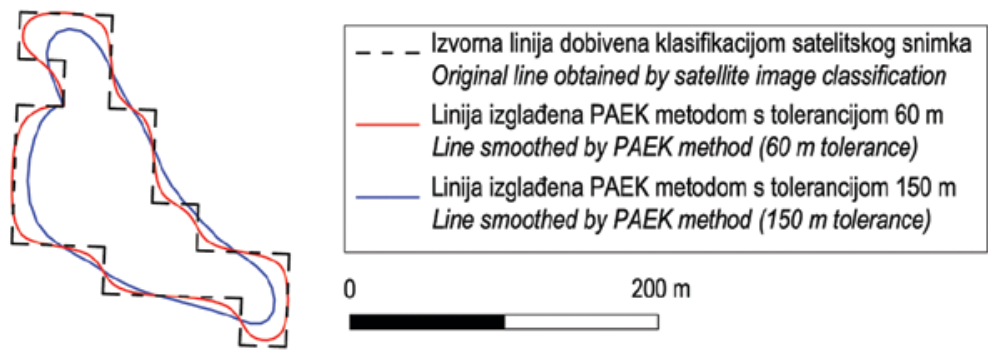

Slika 6. Efekti izglađivanja obrisa šumskog područja PAEK metodom s različitim iznosima tolerancije.

Figure 6 . The effects of smoothing the boundary of the forest area by PAEK method with different amounts of tolerance.

linija koje daju nerealističnu sliku tih objekata u stvarnosti (slika 5).

Za izglađivanje linijskih kartografskih objekata korištena je metoda PAEK (engl. Polynomial Approximation with Exponential Kernel - polinomna aproksimacija s eksponencijalnom jezgromm), u okviru programskog paketa ArcGIS (ESRI: ArcGIS Resources, http://resources.arcgis.com), koja se pokazala puno boljom od interpolacije Bézierovom krivuljom. PAEK je zasnovan na algoritmu izglađivanja, kojeg su razvili Bogdansky i sur. (2002). Algoritam obuhvaća računanje koordinata točaka izglađene linije temeljem opće aritmetičke sredine, konvolucijske jezgre i lokalne aproksimacije polinomom drugog stupnja. Stupanj izglađivanja linije ovisi o jednom parametru, a to je duljina "pokretnog“ puta („moving“ path, često se naziva i tolerancijom) (Giannini i Parente 2015). Veća tolerancija rezultira većom izglađenošću linije, dok se manjom tolerancijom zadržava više detalja izvorne linije (Saeedrashed 2014).

U okviru istraživanja pojednostavljenje obrisa šumskih kompleksa obavljeno je s tolerancijama u iznosu $30 \mathrm{~m}, 60$ $\mathrm{m}, 90 \mathrm{~m}, 120 \mathrm{~m}, 150 \mathrm{~m}$ i $180 \mathrm{~m}$. Te vrijednosti odgovaraju jednostrukoj, dvostrukoj, trostrukoj, četverostrukoj, peterostrukoj i šesterostrukoj rezoluciji razmatrane Landsat snimke. Rezultate izglađivanja jednog poligona prikazuje slika 6.

\section{Ocjena položajne točnosti obrisa šumskih područja - Position accuracy assessment of the boundary of forest areas}

S ciljem ispitivanja položajne točnosti obrisa šumskih kompleksa potrebno je kreirati koridore (engl. buffer - područje oko značajke) širine $x$ oko referentnih linija dobivenih s topografske karte, pri čemu se računa postotak $p$ dužine testne linije dobivene klasifikacijom satelitske snimake, koja se nalazi u okviru poligona koridora. Ako se $p(x)$ poistovjeti s kumulativnom funkcijom distribucije tada će vrijediti $p(0)$ $=0 \mathrm{i} p(\infty)=1$. Uspostavi li se analogija s iznalaženjem mjere kvalitete točkastih objekata, ovdje bi trebalo odrediti $x$ za zadanu vrijednost $p$. U tome se smislu unaprijed definira vrijednost $y$, te se iznalazi procedura za određivanje $x$, tako da vrijedi $p(x)=y$. $\mathrm{U}$ ovu svrhu se može primijeniti iterativni postupak, kojeg su za potrebe ocjene točnosti linijskih elemenata dobivenih digitalizacijom analognih karata predložili Goodchild i Hunter (1996):

1. Inicijalizirati početno rješenje $x_{0}=0 \mathrm{i} p_{0}=0 \mathrm{i}$ izračunati percentilu $y$. Odabrati inicijalnu vrijednost $x_{1}$ temeljenu na dostupnim pokazateljima položajne točnosti. Postaviti $i=1$.

2. Kreirati koridor širine $x_{i}$ oko referentnog objekta i odrediti postotak $p_{i}$ testnog objekta u području obuhvata koridora. Ukoliko je $\left|p_{i}-y_{i}\right|<0.001$ postupak se zaustavlja.

3. Izračunati novu procjenu za $x$ temeljenu na linearnoj aproksimaciji za funkciju $p$ :

$$
x_{i+1}=\frac{\left(y-p_{i-1}\right) \cdot\left(x_{i}-x_{i-1}\right)}{\left(p_{i}-p_{i-1}\right)}+x_{i-1} .
$$

4. Postaviti $i=i+1$ i ići na iterativni $\operatorname{korak}(2)$.

Kako funkcija $p(x)$ mora biti jednolično rastuća, postojat će samo jedno rješenje za $p(x)=y$.

Ispitivanje položajne točnosti prema opisanom postupku obavljeno je pomoću 20 testnih segmenata obrisa šumskih kompleksa (slika 7). Naime, ukupna dužina neizglađenih obrisa 414 šumskih poligona na području istraživanja iznosi $1.284,7 \mathrm{~km}$, tako da bi ocjena točnosti svih poligona bila vremenski izuzetno zahtjevna. Stoga je odlučeno da se koriste testni segmenti poligona (linije), koji su ravnomjerno raspoređeni na području istraživanja. Ukupna dužina testnih linija je 106,5 km, što iznosi približno $10 \%$ ukupne dužine granica šuma.

S ciljem usporedbe testnih i referentnih linija najprije je bilo potrebno sve podatke dovesti u isti referentni koordinatni sustav, tj. obaviti transformaciju koordinata između globalnog i nacionalnog referentnog koordinatnog sustava. $U$ tu svrhu korištena je 3D slična metoda međudatumske transformacije na temelju transformacijskih parametara određenih iz 21 istovjetne geodetske točke na području Sarajeva (Tuno 2014). Položajno standardno odstupanje transformacije izvedene na taj način je $3 \mathrm{~cm}$, što je beznačajno u odnosu na ostale pogreške testnih i referentnih linija. 


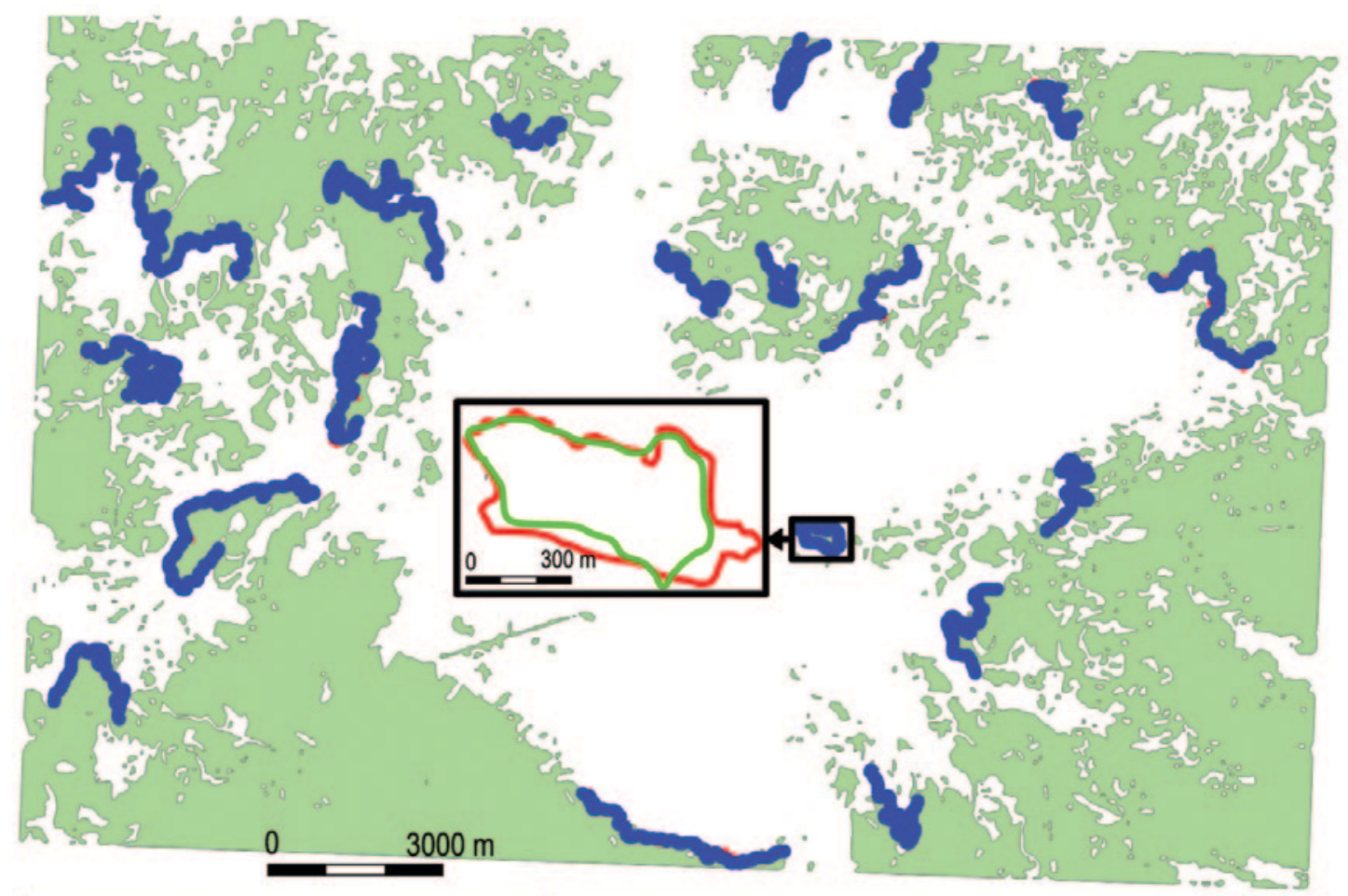

\begin{tabular}{|l|l|}
\hline $\begin{array}{l}\text { Testirani dio obrisa šumskog područja } \\
\text { A segment of the boundary of forest } \\
\text { area to be tested }\end{array}$ & $\begin{array}{l}\text { Referentna linija dobivena digitalizacijom topografske karte } \\
\text { Reference line created by digitizing of topographic map }\end{array}$ \\
$\square \begin{array}{l}\text { Područje prekriveno šumom } \\
\text { The area of land covered by forests }\end{array}$ & Linija dobivena klasifikacijom satelitskog snimka \\
Line created by satellite image classification
\end{tabular}

Slika 7. Testirani dijelovi obrisa šumskog područja na području istraživanja.

Figure 7. A segments of the boundary of forest area to be tested on a experimental site.

Tablica 2. Ocjena točnosti linijskih elemenata.

Table 2. Positional accuracy estimates of linear features.

\begin{tabular}{|c|c|c|c|c|}
\hline \multirow{3}{*}{\multicolumn{2}{|c|}{$\begin{array}{l}\text { Način izglađivanja } \\
\text { obrisa šuma } \\
\text { Method of the forest } \\
\text { boundary lines } \\
\text { smoothing }\end{array}$}} & $\begin{array}{l}\text { RMSE - položajna } \\
\text { točnost obrisa šuma } \\
\text { s pouzdanošću } 68,27 \%\end{array}$ & $\begin{array}{l}\text { CMAS - Položajna } \\
\text { točnost obrisa šuma } \\
\text { s pouzdanošću } 90 \%\end{array}$ & \multirow{3}{*}{$\begin{array}{l}\text { Polinomna regresivna krivulja } \\
\text { Polynomial regression curve }\end{array}$} \\
\hline & & $\begin{array}{l}\text { Positional accuracy } \\
\text { of the forest boundary } \\
\text { lines at the 68,27\% } \\
\text { confedence level }\end{array}$ & $\begin{array}{l}\text { Positional accuracy } \\
\text { of the forest boundary } \\
\text { lines at the } 90 \% \\
\text { confedence level }\end{array}$ & \\
\hline & & (m) & (m) & \\
\hline \multicolumn{2}{|c|}{$\begin{array}{l}\text { Neizglađene linije } \\
\text { Unsmoothed lines }\end{array}$} & 22.2 & 44.3 & $y=-5 E-11 x^{6}+4 E-08 x^{5}-1 E-05 x^{4}+0.001 x^{3}-0.122 x^{2}+5.366 x-4.747$ \\
\hline \multirow{6}{*}{ 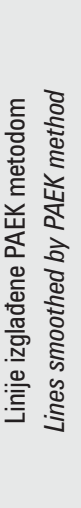 } & $\begin{array}{l}\text { Tolerancija } 30 \mathrm{~m} \\
\text { Tolerance } 30 \mathrm{~m}\end{array}$ & 21.8 & 43.6 & $y=-6 E-11 x^{6}+4 E-08 x^{5}-1 E-05 x^{4}+0.001 x^{3}-0.128 x^{2}+5.489 x-4.788$ \\
\hline & $\begin{array}{l}\text { Tolerancija } 60 \mathrm{~m} \\
\text { Tolerance } 60 \mathrm{~m}\end{array}$ & 21.3 & 42.8 & $y=-7 E-11 x^{6}+5 E-08 x^{5}-1 E-05 x^{4}+0.001 x^{3}-0.134 x^{2}+5.606 x-4.539$ \\
\hline & $\begin{array}{l}\text { Tolerancija } 90 \mathrm{~m} \\
\text { Tolerance } 90 \mathrm{~m}\end{array}$ & 20.8 & 41.8 & $y=-8 E-11 x^{6}+5 E-08 x^{5}-1 E-05 x^{4}+0.001 x^{3}-0.143 x^{2}+5.830 x-5.545$ \\
\hline & $\begin{array}{l}\text { Tolerancija } 120 \mathrm{~m} \\
\text { Tolerance } 120 \mathrm{~m}\end{array}$ & 20.6 & 41.3 & $y=-8 E-11 x^{6}+5 E-08 x^{5}-1 E-05 x^{4}+0.001 x^{3}-0.144 x^{2}+5.854 x-5.467$ \\
\hline & $\begin{array}{l}\text { Tolerancija } 150 \mathrm{~m} \\
\text { Tolerance } 150 \mathrm{~m}\end{array}$ & 20.6 & 41.0 & $y=-8 E-11 x^{6}+5 E-08 x^{5}-1 E-05 x^{4}+0.001 x^{3}-0.142 x^{2}+5.811 x-5.01$ \\
\hline & $\begin{array}{l}\text { Tolerancija } 180 \mathrm{~m} \\
\text { Tolerance } 180 \mathrm{~m}\end{array}$ & 20.9 & 41.0 & $y=-7 E-11 x^{6}+5 E-08 x^{5}-1 E-05 x^{4}+0.001 x^{3}-0.139 x^{2}+5.798 x-6.127$ \\
\hline
\end{tabular}


Tablica 3. Postotci testnih linija unutar koridora u odnosu na njihovu širinu.

Table 3. The percentages of test lines inside the buffer in terms of its width.

\begin{tabular}{|c|c|c|c|c|c|}
\hline \multirow{3}{*}{$\begin{array}{l}\text { Širina koridora } \\
\text { Buffer width } \\
\text { (m) }\end{array}$} & \multicolumn{2}{|c|}{$\%$ testnih linija unutar koridora } & \multirow{3}{*}{$\begin{array}{l}\text { Širina koridora } \\
\text { Buffer width } \\
\text { (m) }\end{array}$} & \multicolumn{2}{|c|}{$\begin{array}{l}\% \text { testnih linija unutar koridora } \\
\% \text { of tested lines within buffer }\end{array}$} \\
\hline & Neizglađene linije & $\begin{array}{l}\text { PAEK izglađivanje } \\
\text { (tolerancija } 180 \mathrm{~m} \text { ) }\end{array}$ & & \multirow{2}{*}{$\begin{array}{l}\text { Neizglađene linije } \\
\text { Unsmoothed lines }\end{array}$} & \multirow{2}{*}{$\begin{array}{l}\text { PAEK izglađivanje } \\
\text { (tolerancija } 180 \mathrm{~m} \text { ) } \\
\text { PAEK smoothing } \\
\text { (180 m tolerance) }\end{array}$} \\
\hline & Unsmoothed lines & $\begin{array}{l}\text { PAEK smoothing } \\
\text { (180 m tolerance) }\end{array}$ & & & \\
\hline 5 & 19.71 & 20.09 & 90 & 98.29 & 98.71 \\
\hline 10 & 37.21 & 38.56 & 100 & 98.78 & 99.08 \\
\hline 15 & 52.57 & 54.62 & 110 & 99.16 & 99.41 \\
\hline 20 & 64.31 & 67.11 & 120 & 99.46 & 99.62 \\
\hline 25 & 73.37 & 75.95 & 130 & 99.61 & 99.78 \\
\hline 30 & 79.75 & 81.81 & 140 & 99.77 & 99.89 \\
\hline 40 & 87.19 & 88.43 & 150 & 99.87 & 99.92 \\
\hline 50 & 91.73 & 92.94 & 160 & 99.92 & 99.99 \\
\hline 60 & 94.80 & 95.99 & 170 & 99.98 & 100.00 \\
\hline 70 & 96.54 & 97.28 & 180 & 100.00 & 100.00 \\
\hline 80 & 97.56 & 98.17 & & & \\
\hline
\end{tabular}
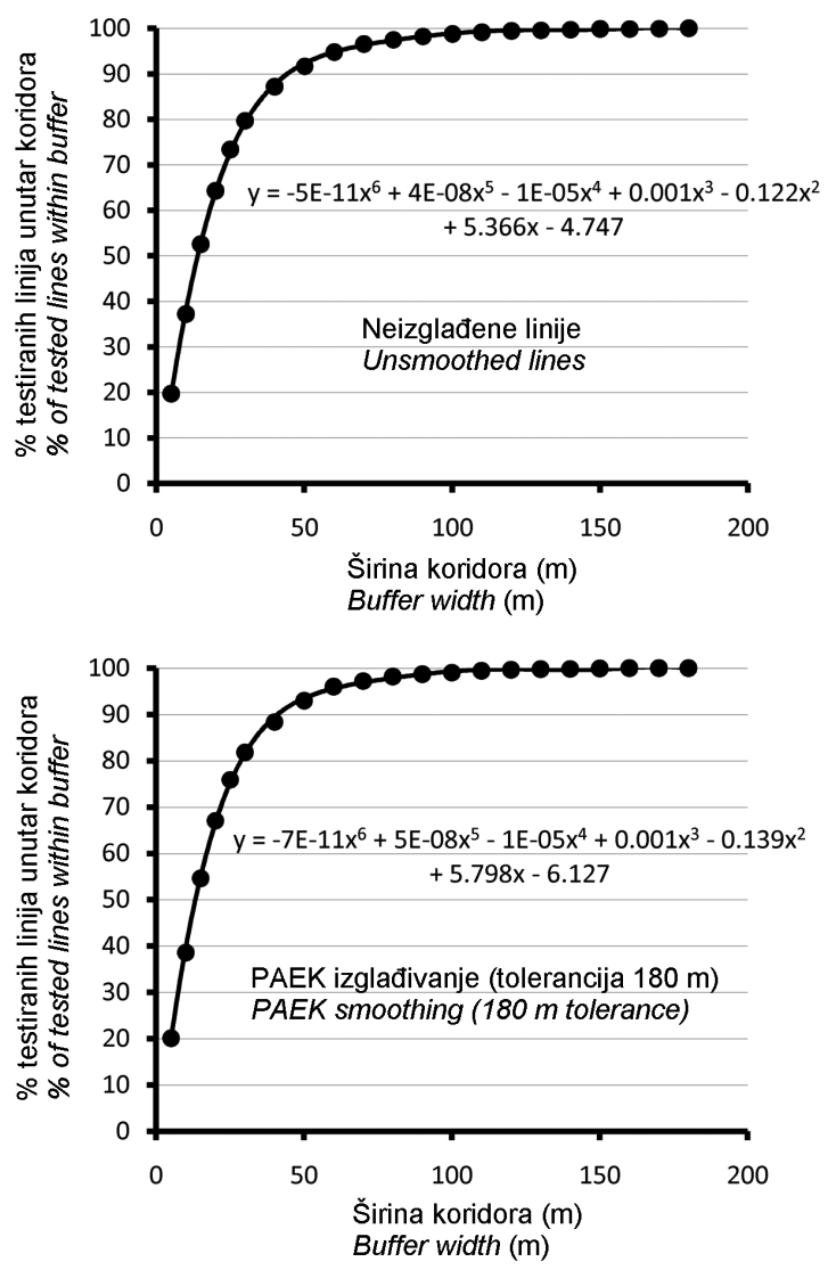

Slika 8. Prikaz postotaka testnih linija koje se prostiru u okviru koridora u ovisnosti o širini koridora.

Figure 8. Plot of the percentage of test lines lying within the buffer depending on the buffer width.
Osnovni statistički pokazatelji ispitivanja točnosti linija obrisa šumskih cjelina prikazani su u tablici 2, zajedno s polinomnim regresivnim krivuljama odnosa širina koridora i postotaka testnih linija unutar tih koridora. Tablica 2 daje vrijednosti drugog korijena srednje kvadratne pogreške (Root Mean Squared Error - RMSE), koja predstavlja mjeru odstupanja testnih podataka od odgovarajućih referentnih (,istinitih“) podataka s pouzdanošću $68.27 \%$, kao i nesigurnosti dvodimenzionalnog položaja koje se izražavaju kao krug pogreške s pouzdanošću od $90 \%$ (Circular Map Accuracy Standard - CMAS, prema NATO normi za ocjenu točnosti topografskih karata STANAG 2215) (Ariza i Atkinson 2008). Promatrajući pokazatelje u tablici 2 vidljivo je da se provedena kartografska generalizacija testnih linijskih elemenata pozitivno odražava na njihovu točnost. Najbolji rezultati ostvareni su izglađivanjem PAEK metodom s tolerancijom $150 \mathrm{~m}$, čime je postignuto poboljšanje položajne točnosti za približno $7 \% \mathrm{u}$ odnosu na neizglađene linije. Treba istaći da dobiveni iznos RMSE $=20.6 \mathrm{~m}$ predstavlja relativnu mjeru točnosti testiranih podataka u odnosu na referentne podatke. Uzimajući u obzir apsolutnu točnost referentnih linija, te činjenicu da su pogreške testiranih i referentnih podataka neovisne, može se izračunati procjena apsolutne položajne točnosti linijskih objekata dobivenih klasifikacijom satelitske snimke. $S$ tim u svezi, apsolutna vrijednost CMAS (prema STANAG 2215) iznosi $49.1 \mathrm{~m}$.

$S$ ciljem boljeg uvida u dobivene rezultate izračunate su vjerojatnosti $p(x)$ za niz diskretnih vrijednosti $x$, što za neizglađene obrise šumskih kompleksa i obrise izglađene PAEK metodom (tolerancija $180 \mathrm{~m}$ ) prikazuje tablica 3. $\mathrm{Na}$ slici 8 jasno se uočava da polinomna regresivna krivulja 6 . stupnja pokazuje vrlo dobar odnos između korištenih širina koridora i postotaka testnih linija unutar tih koridora. Iako 
ove krivulje oblikom podsjećaju na kumulativnu funkciju normalne distribucije, rezultati provedenih Jarque - Bera statističkih testova pokazuju da se empirijska distribucija signifikantno razlikuje od normalne razdiobe. To znači da odstupanja testnih od referentnih linija obrisa šumskih kompleksa nisu normalno raspoređena, što ukazuje na prisutnost grubih i sustavnih pogrešaka. Tako npr. kod linijskih objekata dobivenih PAEK izglađivanjem s tolerancijom $180 \mathrm{~m}$, približno $4 \%$ odstupanja prelazi vrijednost trostruke RMSE, te se mogu smatrati grubim pogreškama. Maksimalne pogreške dosežu vrijednost šesterostruke rezolucije izvorne Landsat snimke.

\section{ZAKLJUČCI CONCLUSIONS}

U opisanom istraživanju pokazano je kako se objektno orijentiranom klasifikacijom multispektralnih satelitskih snimaka srednje rezolucije mogu dobiti kvalitetni vektorski podaci koji predstavljaju granice šumskih područja. Kroz provjeru točnosti obavljene klasifikacije potvrđen je vrlo dobar odabir interpretiranih klasa šumskog pokrova. S ciljem procjene stvarne praktične vrijednosti dobivenih geoprostornih podataka, obavljeno je ispitivanje apsolutne geodetske položajne točnosti. U radu je prikazana posebna metodologija ocjene položajne točnosti linija obrisa šumskih kompleksa, koje su vrlo nepravilnog oblika i rasprostiru se na velikom području. Opisana procedura temelji se na određivanju odnosa testiranog s referentnim izvorom podataka, kroz utvrđivanje dužina testiranih linija koje se nalaze u okviru zadane udaljenosti od referentne linije. Takav pristup je robustan i jednostavan za implementaciju u GIS-u, a ima niz prednosti u odnosu na tradicionalne metode ocjene položajne točnosti, utemeljene na terenskim metodama izmjere. Izglađivanjem linijskih kartografskih objekata PAEK metodom eliminiran je neprirodni efekt nazubljenosti prouzročen prostornom rezolucijom izvornih rasterskih podataka, a s druge strane pokazano je kako kartografska generalizacija doprinosi poboljšanju točnosti obrađenih elemenata. Kvantitativnim ispitivanjem udaljenosti testnih i referentnih kontura šumskih cjelina pokazano je da se podaci dobiveni predstavljenom metodologijom mogu koristiti za prikazivanje površina pod šumama na kartografskim proizvodima A klase, u mjerilima 1:100 000 i sitnijim (u skladu s normom STANAG 2215). S obzirom da je relativno velik dio linija obrisa šumskih kompleksa opterećen grubim pogreškama, nužno je rezultate objektno - orijentirane klasifikacije kontrolirati vizualnom analizom i interpretacijom satelitskih snimaka.

\section{LITERATURA}

\section{REFERENCES}

- Ariza, L. F., G. A. Atkinson, 2008: Analysis of Some Positional Accuracy Assessment Methodologies, Journal of Surveying Engineering, 134 (2): 45-54.
- Bodansky, E., A. Gribov, M. Pilouk, 2002: Smoothing and Compression of Lines Obtained by Raster-to-Vector Conversion, U: W. Liu, J. Llados, J. Ogier (ur.), Graphics Recognition: Algorithms and Applications. Springer, Springer Verlag, 256-265, Berlin - New York.

- Droppová, V., 2011: The tools of automated generalization and building generalization in an ArcGIS environment, Slovak Journal of Civil Engineering, 19 (1): 1-7.

- ESRI: ArcGIS Resources, (http://resources.arcgis.com), (datum pristupa: 10.08. 2015).

- Frančula, N., 2003: Kartografska generalizacija, Geodetski fakultet Sveučilišta u Zagrebu, 117 str., Zagreb.

- Frančula, N., M. Lapaine, 2008: Mali rječnik digitalne kartografije, Kartografija i geoinformacije, 10: 132-143.

- Franklin, S. E., 2001: Remote Sensing for Sustainable Forest Management, CRC Press, 424 str., Florida, Boca Raton.

- Giannini, M. B., C. Parente, 2015: An object based approach for coastline extraction from Quickbird multispectral images, International Journal of Engineering and Technology, 6: 26982704.

- Goodchild, M. F., G. J. Hunter, 1997: A simple positional accuracy measure for linear features, International Journal of Geographical Information Science, 11 (3): 299-306.

- Govedarica, M., A. Ristić, D. Jovanović, M. Herbei, F. Sala, 2015: Object Oriented Image Analysis in Remote Sensing of Forest and Vineyard Areas, Bulletin Horticulture, 72 (2): 362-370.

- Heinonen, T., M. Kurttila, T. Pukkala, 2007: Possibilities to aggregate raster cells through spatial optimization in forest planning, Silva Fennica, 41 (1): 89-103.

- Ključanin, S., D. Petrovič, M. Vajnaga, 2011: Ocjena točnosti državne topografske karte mjerila 1:25000, Geodetski glasnik, 40: 37-49.

- Mulahusić, A., N. Tuno, 2011: Metode za otkrivanje promjena kod daljinskih istraživanja, Geodetski glasnik, 40: 3-13.

- Oštir, K., A. Mulahusić, 2014: Daljinska istraživanja, Građevinski fakultet Univerziteta u Sarajevu, 343 str., Sarajevo.

- Puceković, B. 2014: Ispitivanje točnosti topografske karte u mjerilu 1:25 000 u izdanju Vojnogeografskog instituta u Beogradu, Geodetski list, 91 (1): 33-46.

- Radojčić, S., Borisov, M., Božić, B. 2011: Položajna tačnost geografskih informacija i savremeni standardi za njeno ocenjivanje. Glasnik Srpskog geografskog društva, 91 (2): 99-112.

- Ruiz-Lendínez, J. J., F. J. Ariza-López, M. A. Ureña-Cámara, 2013: Automatic positional accuracy assessment of geospatial databases using line-based methods, Survey Review 45 (332): 332-342.

- Saeedrashed, Y. S. 2014: An Experimental Comparison of Line Generalization Algorithms in GIS, International Journal of Advanced Remote Sensing and GIS, 3 (1): 446-466.

- Seletković, A., R. Pernar, A. Jazbec, M. Ančić, 2008: Točnost klasifikacije satelitske snimke visoke prostorne rezolucije ikonos za potrebe šumarstva, Šumarski list, 9-10: 393-404.

- Skopeliti, A., L. Tsoulos, 2000: Estimating Positional Accuracy of Linear Features (http://www.fig.net/com_3_athens/pdf/ S55.\%20A.Skopeliti,\%20L.Tsoulos.pdf). Spatial Information Management - Experiences and Visions for the 21st Century, Workshop of FIG-Commission 3, Athens, Greece, 4-7 October (datum pristupa: 14.02.2016.). 
- Tarmizi, N. M., A. M. Samad, M. S. C. Mat, M. S. M. Yusop, 2014: Qualitative and Quantitative Assessment on Shoreline Data Extraction from Quickbird Satellite Images, International Journal Of Computer Science, 2 (9): 54-62.

- Trimble: eCognition Essentials, (http://www.ecognition.com/), (datum pristupa: 10.11. 2015).

- Tucker, C. J., D. M. Grant, J. D. Dykstra, 2004: NASA's global orthorectified Landsat data set, Photogrammetric Engineering and Remote Sensing, 70: 313-322.

- Tuno, N., 2014: Optimalne metode geometrijske obrade digitalnih geodetskih planova, Doktorska disertacija. Građevinski fakultet Univerziteta u Sarajevu.
- Tutić, D., M. Lapaine, 2009: Kartografska generalizacija linija sa svojstvom čuvanja površina, Kartografija i geoinformacije, 11: 84-100.

- Valožić, L., 2014: Klasifikacija zemljišnog pokrova urbanog i periurbanog prostora pomoću objektno orijentirane analize multispektralnih snimaka, Hrvatski geografski glasnik, 76/2: 27 $-38$

- Vojniković, S., J. Taletović, B. Balić, M. Ljuša, O. Žurovec, H. Čustović, 2013: Procjena površina šuma u Kantonu Sarajevu prema 4tom nivou nomenklature Corine zemljišnog pokrivača, Naše šume, 32-33: 12-22.

\section{Summary}

Knowledge about positional accuracy of forest geospatial information, obtained by interpretation of satellite imagery, is of great significance. The consequences of the decisions that are based on data with insufficient or unknown quality could be very negative. This paper investigates the accuracy of closed linear shapes that represented boundaries of forest cover. Forest areas are effectively extracted from Landsat image by implementing the process of multiresolution image segmentation (figure 4), using all bands. Multispectral classification of defined segments was performed by special rules. The results of object-oriented classification showed that an overall accuracy from 99 reference points was better than $90 \%$ (table 1), which can be considered as a very good result. The number of forest polygons, obtained by satellite imagery classification, was reduced by 37 times by cartographic aggregation (figure 5). The Polynomial Approximation with Exponential Kernel (PAEK) method was used for cartographic smoothing of the forest polygons, which smoothes lines in relation to a softening tolerance (tolerances from $30 \mathrm{~m}$ to $180 \mathrm{~m}$ were used in this research) (figure 6). The positional accuracy assessment of the boundary of forest areas, based on procedure of comparing a tested lines to a reference lines, showed that the best results were obtained by PAEK smoothing with $150 \mathrm{~m}$ and $180 \mathrm{~m}$ tolerances (CMAS $=49 \mathrm{~m}$, according to STANAG 2215) (tables 2 and 3, figure 8).

The findings of this empirical research showed that cartographic generalization contributes to improvement of the forest boundaries accuracy, as well as the appropriate processing of the medium spatial resolution remotely sensed data can result in satisfactory quality of vector data.

KEY WORDS: Landsat, object-oriented forest classification, cartographic generalization, positional accuracy 